\title{
Modified clay for the synthesis of clay-based nanocomposites
}

David P. PENALOZA Jr. Associate professor in the Chemistry Department, College of Science, De La Salle University. His research interests focus on self-assembled systems and nanostructured materials.

David P. PENALOZA JR. - Chemistry Department, College of Science, De La Salle University, Manila

- david.penaloza.jr@dlsu.edu.ph

Érkezett: 2018. 08. 12. " Received: 12. 08. 2018. " https://doi.org/10.14382/epitoanyag-jsbcm.2019.2

\begin{abstract}
This review article highlights usual surface modification methodologies in clay fillers for polymer nanocomposites. In clay-based polymer nanocomposites preparation, a key step is the homogeneous dispersion and random orientation of the silicate platelets, like that of montmorillonite (MMT), in the polymer matrix resulting in an exfoliated nanohybrid materials, where significant works in the literature support enhanced and/or new properties of the resulting nanocomposites compared to the bare polymer. In incorporating the MMT clay as a filler in a polymeric material, the surface modification of an MMT clay is necessary. An MMT clay is made up of layered silicates carrying negative charges held together by metal cations found in the galleries between the clay layers. If left unmodified, the native clay exists as aggregates. To improve its miscibility toward organic molecules, it is necessary to modify the clay fillers for polymer nanocomposites.
\end{abstract}

Keywords: Silicate clay, clay modification, montmorillonite, organoclay

Kulcsszavak: Szilikátos agyag, agyag modifikálás, montmorillonit, szerves agyag

\section{Introduction}

A polymer-clay nanocomposite represents a new class of hybrid materials composed of an organic polymer matrix with an inorganic clay acting as a filler material having at least one dimension in the nanometer range. A fully exfoliated, individual clay platelet is about a nanometer in thickness. At this length scale, the presence of these individual nanometer thin platelets dispersed in the polymer matrix even at a low amount of the silicate filler ( $<10 \%$ by wt) can impact the resulting hybrid organic-inorganic material to exhibit greatly enhanced and new properties relative to the neat polymer [19]. These new and enhanced properties observed for these nanomaterials have found numerous applications and have attracted the attention of both the academe and the industries. The homogeneous dispersion of these nanometer-sized silicate platelets within a polymer matrix can lead to the formation of a hybrid material that exhibits markedly improved properties such as higher modulus, increased thermal stability and flame retardancy, and more efficient gas barrier properties, as compared to their unfilled polymers or conventional composites counterparts.

Among the clay fillers, the montmorillonite (MMT) clay is the usual choice in preparing most polymer-clay nanocomposites because of its individual nanometer-thick platelets, extremely large surface areas, rich intercalation and surface chemistry [10-12]. Further, this type of clay is universally abundant in nature and can be obtained in pure form at a low cost.

An MMT clay, being hydrophilic in nature, obviously would only be miscible with hydrophilic polymers like poly(ethylene oxide), poly(vinyl alcohol), etc. Generally, it would be very difficult to mix this clay with hydrophobic polymers because of its pristine hydrophilic nature. If left unmodified, it would be very difficult to achieve a homogeneous of clay and polymer where the clay filler is randomly well distributed in the hydrophobic polymer matrix [13]. In any nanocomposite preparation, one major challenge is the achievement of a high degree of exfoliation of the aluminosilicate layered structure to yield well-dispersed individual clay platelets in the nanocomposite. This type of morphology for the clay is the target of most modification techniques since the exfoliation of the clay fillers creates a bulk material of interfaces as opposed to the intercalation or agglomeration of the layered silicates in the composite material [14-16]. Hence, modifying the clay filler prior to its incorporation in various polymeric matrices has been usually observed.

\section{Montmorillonite clay}

Montmorillonite (MMT) clay is a naturally-occurring hydrous aluminum silicate clay belonging to a class of clay known as 2:1 phyllosilicates. The clays belonging to this class are commonly regarded as layered silicates [17]. Other layered silicate clays aside from MMT clay include vermiculite, saponite and hectorite (Table 1). The MMT clay has a layered morphology consisting of stacks of silicate platelets that are about 1-nm thick and about $300 \mathrm{~nm}$ to a few microns in lateral dimensions. Each individual platelet has a central octahedral sheet of alumina fused between two external silica tetrahedral sheets (Fig. 1). The tetrahedral sheet is mainly composed of silica while the octahedral sheet is comprised of diverse elements like $\mathrm{Al}, \mathrm{Mg}$ and $\mathrm{Fe}$ [18]. The stacking of the layers leads to a regular van der Waals gap called the interlayer or gallery. Isomorphic substitution (for example, $\mathrm{Al}^{3+}$ replaced by $\mathrm{Mg}^{2+}$ or $\mathrm{Fe}^{2+}$ ) within the layers generates negative charges that are counterbalanced by cations residing in the interlayers (Fig. 2). In their pristine form, their excess negative charge is balanced by cations $\left(\mathrm{Na}^{+}, \mathrm{Li}^{+}, \mathrm{Ca}^{2+}\right)$ which exist hydrated in the interlayers. The cations are held very loosely and can be readily exchanged by other cations. 


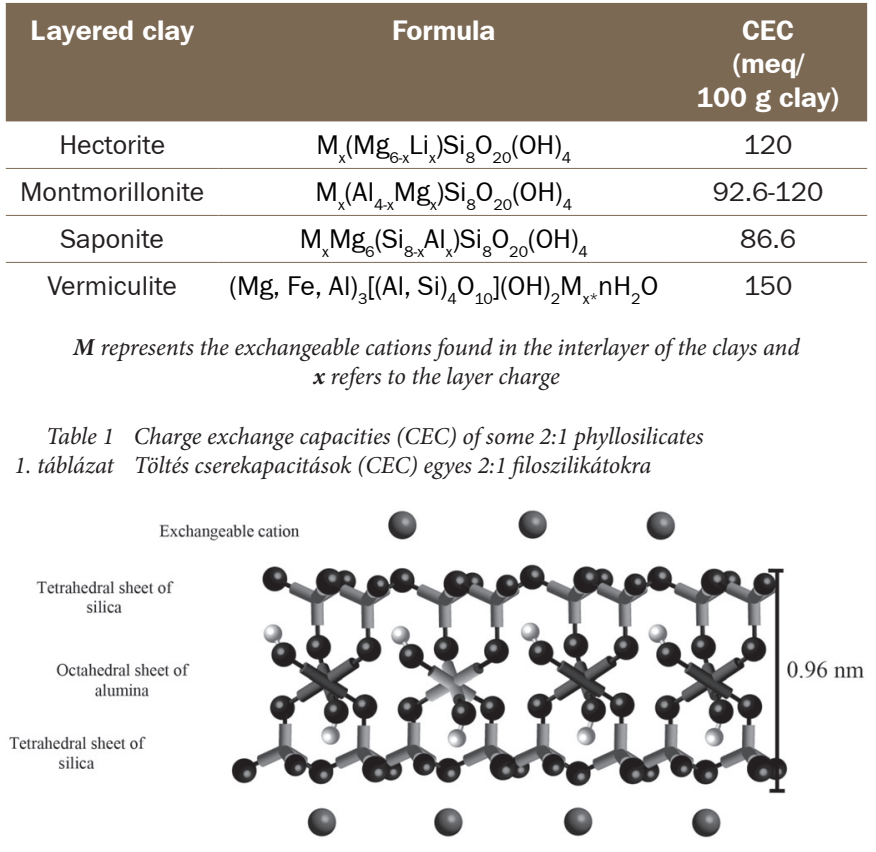

Fig. 1. An individual montmorillonite clay platelet is about a nanometer thick and is composed of an octahedral sheet of alumina sandwiched by two tetrahedral sheets of silica. Isomorphic substitution (for example, $\mathrm{Al}^{3+}$ replaced by $\mathrm{Mg}^{2+}$ or $\mathrm{Fe}^{2+}$ ) within the layers generates negative charges that are counterbalanced by cations residing in the interlayers.

1. ábra Egy kb. 1 nanométer vastagságú montmorillonit lemez, amely egy oktaéderes aluminát lemezböl áll közrefogva két tetraéderes szilikát lemezzel. A lemezek közötti izomorf helyettesités ( $p l$. Al ${ }^{3+}$ ion helyettesitése $\mathrm{Mg}^{2+}$ vagy $\mathrm{Fe}^{2+}$ ionokkal) negatív töltést generál, amelyet a lemezközi kationok kompenzálnak.

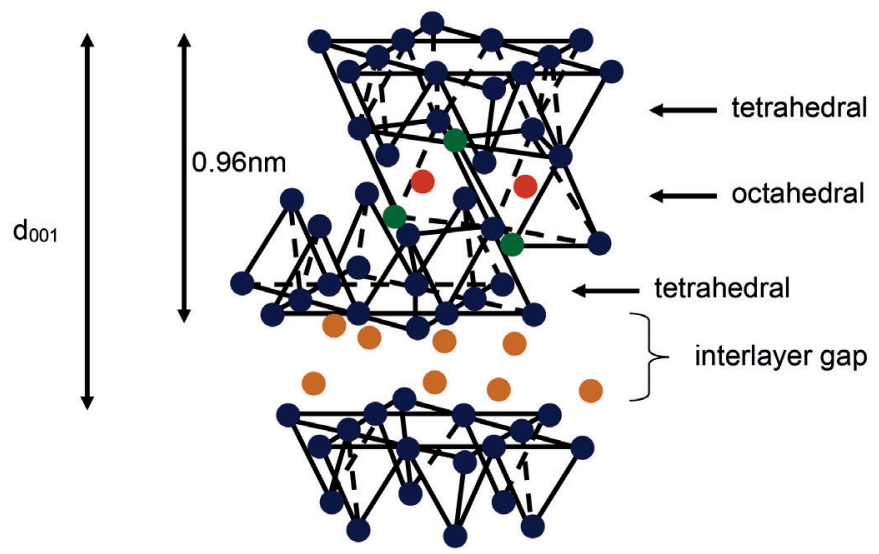

Fig. 2. The stacking of the silicate platelets (each about a nanometer thick) leads to a regular van der Waals gap called the interlayer or gallery. Inside the galleries, highly exchangeable cations are found. Replacement of these ions by alkyl surfactants can lead to the increased distance of the interlayer gaps.

2. ábra A szilikát lemezek kapcsolódása szabályos van der Waals rést eredményez (rétegközi galéria). A galériákon belül erös cserepotenciálú kationok találhatók. Ezek cseréje alkil felületaktív gyökökkel a rétegközi réstávolság növekedéséhez vezet.

There are two attractive features why an MMT clay is commonly exploited in the preparation of polymer-clay nanocomposites. The MMT clay has highly exchangeable ions that are found at the interlayers. These cations can be easily substituted with organic surfactants, i.e. the use of ion exchange reaction. For example, the reaction between an alkyl ammonium salt and the MMT clay results in the replacement of these cations with alkyl chains that increase the interlayer gaps as well as change the surface chemistry of the MMT clay.
Also, the MMT clay has high aspect ratio (100 - 1000) that can be maximized through the dispersion of the individual silicate layers in a polymer continuum. These two characteristics are, of course, interrelated because the ability to disperse the silicate layers in a polymer matrix, thereby maximizing their aspect ratio, depends on the chemical nature of the interlayer cation.

At a low filler loading, usually less than $10 \mathrm{wt} \%$, the reinforcement efficiency of exfoliated silicate platelets as fillers to form polymer-clay nanocomposites can match that of a conventional composite that is usually made using a relatively higher loading (40-50 wt.\%) of classical fillers. This improvement is due to the dispersion of the nanoscale fillers into the matrix, which results in a high surface area with high interactions between the nanoclay and the polymer matrix [19-21].

\section{Clay modification}

In preparing clay-based polymer nanocomposites, a homogeneous dispersion and random orientation of the silicate platelets of the clay filler in the polymer matrix is desired for a fully exfoliated system. Another consideration is the favorable interaction between the polymer and the clay filler in order to avoid phase separation and agglomeration of the filler particles in the polymer matrix. In incorporating the MMT clay as a filler in a polymeric material, the surface modification of an MMT clay is necessary. An MMT clay is made up of layered silicates carrying negative charges held together by metal cations found in the galleries between the clay layers. The presence of metal cations and the ability of forming hydrogen bonds with water contribute to the hydrophilic nature of the pristine MMT. Hence, pristine MMT clay is difficult to mix with an organic matrix especially if it involves hydrophobic polymers. If left unmodified, the native clay exists as aggregates. To improve its miscibility toward organic molecules, it is necessary to modify the surface chemistry of the MMT clay. One method of modification is the replacement of the inorganic cations found in the interlayers with various organic cationic molecules. The intercalation of organic molecules in the clay galleries can lead to the increased interlayer spacing. This surface treatment also makes the clay to become more compatible with polymer molecules. The increased interlayer gap and the favorable interaction posed by the alkyl intercalants found in the clay galleries of the organoclay allow the polymer molecules to enter the enlarged basal spacing of the organoclay for further intercalation and which may eventually lead to the clay exfoliation.

\subsection{Clay modification via ion-exchange reaction}

To make the hydrophilic clay more compatible with the polymer matrix, surface modification techniques have been commonly employed on clays used as fillers prior to their incorporation in the polymers. An ion exchange reaction between the MMT clay and an ammonium-based alkyl salt as an intercalant [22-26] is one. The clay surface can be converted from being hydrophilic to organophilic via a cation exchange reaction with an alkyl ammonium ion that may include a primary, secondary, tertiary or quaternary alkyl ammonium 
salt. The change in surface property of the clay brought about by an ion exchange reaction can improve the interfacial adhesion properties between the inorganic phase (clay filler) and the organic phase (polymer matrix) when a hydrophobic polymer matrix is involved [27]. The alkyl intercalant of the modified clay can also increase the interlayer distance of the silicate layers where the increase in the basal spacing is affected by the length of the alkyl chain and the ratio of crosssectional area to available area per cation [28]. Long-chain alkyl ammonium-exchanged forms of MMT are the most commonly used in the preparation of most clay-based polymer systems. Quaternary ammonium salts, of the general formula $\left[\mathrm{NR}_{4}\right]^{+} \mathrm{X}^{-}$where $\mathrm{R}$ is a hydrocarbon chain and $\mathrm{X}$ is a halide group, have been commonly employed in the organophilic modification of MMT via an ion exchange reaction [29-31]. This is possible due to the presence of highly exchangeable metal ions residing in the galleries of pristine MMT clays. On the addition of the alkyl ammonium salt to the aqueous clay suspension, the long alkyl cations replace the metal ions originally present in the clay galleries. The ammonium groups become ionically anchored to the negative clay surface with the long hydrocarbon chains radiating away from the clay surface. The intercalation of the organic surfactant not only changes the surface property of the clay (making it more hydrophobic) but also increases the basal spacing of the clay layered structure which favors the intercalation of long polymer molecules.

Depending on the chain length and charge density of the clay, the alkyl chains can adopt several conformations inside the clay galleries. Lagaly (1986) [32] proposed that the alkyl ammonium ions used to modify $2: 1$ clay minerals lie either parallel to the silicate surface forming mono- or bilayers or radiate away from the surface forming paraffin-type arrangement. The organic intercalant may adopt a monolayer, quasi-bilayer or multi-layer configuration based on the length of the alkyl chain [27, 33-36].

Vaia and his co-reresearchers (1994) [36] studied the structure of an organoclay of MMT, modified with dioctadecyl dimethyl ammonium, $\left(\mathrm{CH}_{3}\left(\mathrm{CH}_{2}\right)_{16} \mathrm{CH}_{2}\right)_{2} \mathrm{~N}^{+}\left(\mathrm{CH}_{3}\right)_{2}$, by X-ray diffraction (XRD), infrared spectroscopy (IR), and differential scanning calorimetry (DSC) and showed that the alkyl chains assume an ordered state. That is, the alkyl ammonium cations build a self-assembled monolayer (SAM) on the mineral surface. The authors postulated that the arrangements of the alkyl chains in the clay interlayer vary from solid-like to liquid-like and in intermediate cases, liquid crystalline, depend on the packing density and chain length (Fig. 3). An ordered state for the alkyl chains intercalated in the clay can be observed at a particular length and number of chains due to the increasing chain interactions and the packing density of the tethered chains. At this stage, the chains attached to the platelets are proposed to interdigitate [27]. In the interdigitated arrangement of the tethered alkyl ammonium ions, their conformational entropy is minimized while the packing density of the attached chains is maximized. The authors also proposed that in their ordered state, the alkyl chains inside the MMT galleries preferentially assume an all-trans conformation with the alkyl chains tilted to the MMT surface at an angle (Fig. 3.c) [27, 34-35]. (a)

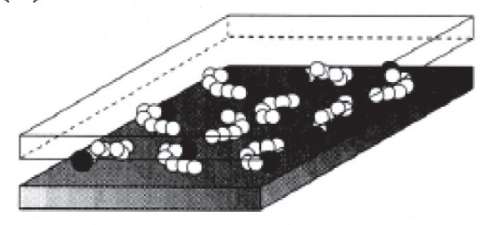

short chains

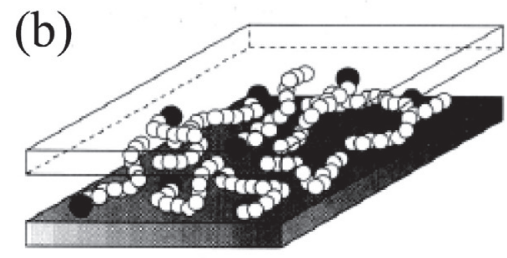

intermediate chains

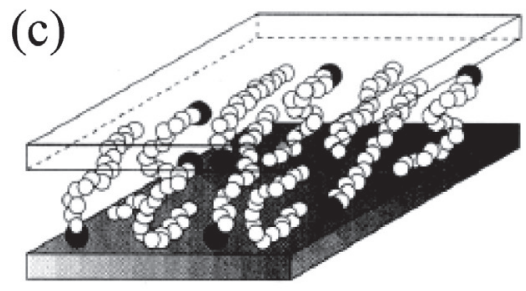

long chains

The organo-modified clays were found to self-assemble parallel to each other inside the clay galleries forming alternating, well-ordered organic/inorganic multi-layers based on molecular dynamic (MD) simulations. Hackett and coworkers (1998) [37] used MD simulations to study the static and dynamic properties of 2:1 layered silicates $(\mathrm{CEC}=0.8,1.0$ and $1.5 \mathrm{meq} / \mathrm{g}$ for two MMT clays and a hectorite, respectively) that are modified with ammonium-based alkyl surfactants. The MD simulations they conducted for these organoclays showed that the basal spacing increased with the length of the alkyl chain of the onium salts used as a modifier. The results further showed that within the gallery, the alkyl chains exhibit layering tendencies. The shorter alkyl chains form a monolayer configuration with an interlayer gap of $1.3 \mathrm{~nm}$. As these chains become longer, bilayer $\left(\mathrm{d}_{001}=1.8 \mathrm{~nm}\right)$ and trilayer $\left(\mathrm{d}_{001}=2.27\right.$ $\mathrm{nm}$ ) disordered arrangements can be observed.

Okutomo et al. (1999) used various silylating agents having different chain lengths to react with a magadiite clay previously ion exchanged with an alkyl ammonium modifier $\left(\mathrm{C}_{12}\right.$ TMAmagadiite). They reported that an increase in the number of carbon in the alkyl chain corresponds to a larger basal spacing of the resulting organoclay. After silylation, the basal spacing changed from $2.79 \mathrm{~nm}$ (before silylation) to 1.95, 2.33 and

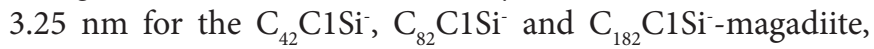
respectively. 
Aside from the ability of the long alkyl ammonium intercalants to increase the clay interlayer spacing, they create a more favorable organophilic environment. The presence of the alkyl chains in the intergalleries of the organoclays lowers the surface energy of the host clay and improves the compatibility of the clay to become more miscible with the organic polymer matrix [38-39].

The amount of alkyl ammonium ions that can be intercalated between the clay layers is based on the charge exchange capacity (CEC) value of the clay being considered as a filler for a polymeric matrix. The candidate filler should have a CEC value between $0.5-2.0 \mathrm{meq} / \mathrm{g}$ of clay. Clays having less than 0.5 $\mathrm{meg} / \mathrm{g}$ clay would lead to a small amount of organic intercalant after an ion exchange reaction. More than $2.0 \mathrm{meq} / \mathrm{g}$ of clay exchange capacity, the strength of the interlayer bonding is too high for easy intercalation [40]. Hence, montmorillonite clays having a CEC value of $0.93-1.2 \mathrm{meq} / \mathrm{g}$ of clay and vermiculites $(\mathrm{CEC}=1.5 \mathrm{meq} / \mathrm{g})[41]$ are ideal templates for intercalation.

The ion exchange reaction of these alkyl ammonium salts with the clay is reversible. Thus, in order to ensure a high conversion of a pristine MMT clay like in the case of sodium montmorillonite clay, $\mathrm{Na}^{+}-\mathrm{MMT}$, into an organoclay, an excess amount of the intercalating organic cation is usually observed:

$\left[\mathrm{NR}_{4}\right]^{+}+\mathrm{Na}^{+}-\mathrm{MMT}\left[\mathrm{NR}_{4}\right]^{+}-\mathrm{MMT}+\mathrm{Na}^{+}$

Lee and $\operatorname{Kim}$ (2003) [42] did a modification of $\mathrm{Na}^{+}-\mathrm{MMT}$ clay using different amounts of an intercalating agent relative to the cation exchange capacity (CEC) of the clay. The intercalating agent used was a $\mathrm{C}_{16}$ ammonium salt, trimethylhexadecyl ammonium bromide, $\mathrm{CH}_{3}\left(\mathrm{CH}_{2}\right)_{14} \mathrm{CH}_{2} \mathrm{~N}\left(\mathrm{CH}_{3}\right)_{2} \mathrm{Br}$. Different amounts of the intercalating agent were used, ranging from 0 to 3 times the CEC value of the $\mathrm{Na}^{+}$-MMT. After the ion exchange reaction, the XRD profiles of the organoclays were obtained. The interlayer spacing of the produced organoclays was observed to increase with the amount of the alkyl intercalant. From the original value of $\mathrm{d}_{001}=1.4 \mathrm{~nm}$ (for $\mathrm{Na}^{+}-\mathrm{MMT}$ ), the interlayer distance increased to 1.9, 3.2 and $3.9 \mathrm{~nm}$ at a loading of 1, 2 and 3 times the CEC of the clay, respectively.

The alkyl ammonium intercalant can also provide functional groups which can react with the polymer matrix or supply sites for the initiation of a polymerization which can occur in the gaps between the clay platelets. This can be done by the introduction of an intercalating agent that possesses a functionality that can initiate the polymerization. After an ion exchange reaction with the highly exchangeable cations found in the galleries of the MMT layered structure, the tethered organic initiator can start the in situ polymerization where chains can be grown directly from the surface. The significance of an in situ polymerization after intercalation is based on the assumption that as the polymer chain grows, the silicate layers separate far apart until they become eventually exfoliated to form a well dispersed composite material [43]. Zhou et al. (2001) [44] explored this approach to prepare a clay-based polymer nanocomposite where polystyrene chains are directly grown from previously anchored initiators on the clay surfaces. First, the immobilization of a triethyl ammonium cation that contains 1,1-diphenylethylene (DPE) derivative through an ion exchange reaction with the sodium montmorillonite $\left(\mathrm{Na}^{+}-\mathrm{MMT}\right)$ was performed. The DPE served as an initiator precursor. After the addition of n-butyl lithium (n-BuLi) and removal of the free $\mathrm{n}-\mathrm{BuLi}$ from the reaction mixture, the polymerization of styrene was initiated directly from the ionically attached initiators on the clay surfaces.

\subsection{Clay modification via silane-coupling reaction}

One way of increasing the favorable interaction between organic molecules and clay surfaces is by introducing some hydrophobic groups onto the layer surfaces [45-46]. This method of clay modification can be possible with the reaction of silanes with the silanol groups found in the clay layered structure $[10,47-50]$. The said technique makes use of the existing silanol groups found in the clay structure to react with organosilane agents. Silanol groups $(\mathrm{Si}-\mathrm{OH})$ are located on the clay edges due to broken edges and crystalline defects [51-56]. Using a chloroor alkoxysilanes as a modifying agent, several functionalities can be introduced to the clay. Unlike the ion-exchanged clays, the covalently modified clays achieved through the hydrosilylation of the silanol groups are more thermally stable $[47,53]$. More importantly, the characteristics of the modified clays can be easily fine tuned through the introduction of various end groups of the silane modifiers $[52,57]$.

Early studies on the use of silane agents in clay modification targeted the silanols found in the clay structure. In 1976, RuizHitzky et al. [58] used organochlorosilanes to hydrophobize the surfaces of sepiolite and chrysotile - both are examples of silicate materials. They were able to prepare different stable derivatives of the clays using organochlorosilanes. In modifying these layered silicate materials with the use of organosilanes to react with the silanol groups of the clay, they found out that only the external surfaces of the silicate clays can be modified as the grafting reaction can only access the edge silanols. Five years later [59], they reported the successful silylation of the internal silanols of a magadiite clay by suspending this clay in dimethylsulfoxide or N,N-dimethyl formamide. These solvents were able to expand the basal spacing of the layered silicic acid and permit the entry of the silane agent to reach the internal silanols of the $\mathrm{H}$-magadiite. $\mathrm{H}$-magadiite contains a lot of internal silanols which can be reacted with silane agents bearing various functionalities.

Park et al. (2004) [56] found that organic molecules intercalate much faster in the layered structure of laponite clay if the clay was first modified with octyltrimethoxysilane. The authors found that the grafting reaction of the silane agent only happens on the external surfaces of the laponite clay.

The covalent grafting of organosilanes through the reaction with silanols in the clay structure is important since it provides an opportunity to immobilize reactive organic groups to the clay via a stable covalent bond. Of primary interest, however, is to be able to chemically modify the interlayer surfaces of the silicate clay structure using this modification technique. Several authors have shown that this is possible. For example, in the case of Ruiz-Hitzky et al. (1985), after initially modifying the magadiite through the intercalation of polar organic molecules, the magadiite was successfully silylated by various organosilane reagents. The intercalation of polar organic agents increased the gaps between the layers. The grafting of organosilyl groups in the interlamellar space occurs due to 
the larger gaps which make the interlamellar silanol $(\mathrm{Si}-\mathrm{OH})$ groups now more accessible to the silylating reagents [60].

The same success of grafting silane on the surface of kenyaite clay was achieved after performing gelification in the presence of octylamine and reaction at room temperature [61]. Kenyaite was also recently reacted with APTES and dodecylamine in ethanol, resulting in interlayer surface silylation. Magadiite and kenyaite are examples of natural minerals possessing a layered structure [62].

This modification route has been used in tandem with an ion exchange reaction to prepare nanocomposites [48, 63-65]. For example, in the work of Yanagisawa et al. (1988) [66] where they reported the successful silylation of the interlayer surface of layered polysilicic acids using a bulky group-bearing silane, diphenylmethylchlorosilane, utilizing these two methods. The layered acids, $\mathrm{H}$-magadiite and $\mathrm{H}$-kenyaite, were first modified with dodecyltrimethylammonium ion, $\mathrm{CH}_{3}\left(\mathrm{CH}_{2}\right)_{10} \mathrm{CH}_{2} \mathrm{~N}^{+}\left(\mathrm{CH}_{3}\right)_{3}$, to serve as the intermediates for the conversion. The intercalation of the ammonium salts enlarged the interlayer space allowing the bulky silylating agent to be intercalated. It was previously reported by Ruiz-Hitzky et al. (1985) [60] that a bulky silylating agent, like diphenylmethylchlorosilane, cannot be intercalated in these clays.

Some studies reported a combination of these methods to modify silicate clays. Okutomo et al. (1999) [49] for instance, reported the use of both alkyl ammonium modifier and silane agent to modify magadiite, a layered silicate clay. They used an ion exchange reaction technique to intercalate a dodecyltrimethylammonium cation, $\mathrm{CH}_{3}\left(\mathrm{CH}_{2}\right)_{10} \mathrm{CH}_{2} \mathrm{~N}^{+}\left(\mathrm{CH}_{3}\right)_{3}$, in order to increase the basal spacing of the clay. The larger gaps between platelets enabled the bulky chlorosilane to access the interlayer silanol groups of the magadiite clay. They also found out that by increasing the chain length of the silylating agent corresponded to an increase in the basal spacing of the silylated clay, the same effect observed when an alkyl ammonium salts are used as the intercalating agent. The advantage of the former is that the silane agent is attached to the clay by a more stable covalent attachment as opposed to an ionically-tethered ammonium alkyl chain.

He et al. (2005) [47] reported that the grafting reaction involving organosilanes reacting with layered silicates involves two steps. The silane molecules first intercalate into the clay interlayers followed by a condensation reaction between the silane molecules and the silanols of the clay layers.

Zhang et al. (2006) [48] were able to show that it is possible to successfully graft a silylating agent onto the internal surfaces of a silicate clay. This is important as this approach can provide an opportunity to anchor catalysts onto the silicate surfaces and facilitate polymerization inside the galleries. A commercial organoclay from Southern Clay Products, Inc, Cloisite 20A, was used. An MMT clay derivative, modified with naturally-occurring tallow ammonium salt, was reacted with trimethylchlorosilane. The chlorosilane reacted with the edge hydroxyl groups of the clay, in the process, liberating $\mathrm{HCl}$. The protons from the liberated $\mathrm{HCl}$ replaced some of the alkyl ammonium ions ionically attached between the clay platelets leading to the formation of new hydroxyl groups on the internal clay surfaces. Since an excess stoichiometric amount of the silylating agent was used, further silylation of the newly formed -OH groups was observed. The XRD profiles of the clay before and after silylation were compared. The product, TMS$20 \mathrm{H}$, has a smaller basal spacing than the Cloisite $20 \mathrm{~A}$ itself. This smaller gap confirmed the successful intercalation of the silylating agent since it has shorter length that the previously anchored tallow intercalant of Cloisite20A.

In another setup, the authors performed the same silylation process but in the presence of $\mathrm{NaHCO}_{3}$. The authors reasoned out that if the protons from the liberated $\mathrm{HCl}$ during the silylation process were trapped by the hydrogen carbonate ions, only the edge silanol groups react with trimethylchlorosilane and there would be no change in the $d_{001}$ spacing of the Cloisite20A due to the loss of the alkyl chain-bearing modifier. It was found that the silylation does not modify the internal MMT surfaces but only the edges in the presence of the bicarbonate ions as the resulting organoclay, labeled as TMS$20 \mathrm{~A}$, has the same basal spacing as the precursor. The results of the thermogravimetric analysis and infrared spectroscopy also confirmed the presence of the edge trimethylsilyl groups.

\section{Conclusions}

In the preparation of clay-based polymer nanocomposites, one particular challenge in using layered silicates like MMT as additives is getting the clay nanofillers to homogeneously mix with the matrix polymer. Modifying the clay filler before its incorporation in the polymer bulk is thus important. Two common clay modification methodologies are usually carried out: via ion-exchange reactions with alkyl cation salts and through silylation reactions. The most common method to modify clay fillers is to substitute the highly exchangeable cations originally found in the interlayers with long alkyl ammonium salts via ion exchange reactions. The intercalation of the alkyl chains in the galleries of the clay fillers leads to the expansion of the spaces between platelets. The intercalating agents also give more hydrophobic character to the modified clay fillers making them more compatible with organic polymers. Another method of clay modification is using organochlorosilanes. The use of silylation reactions to modify the surface of MMT clays is possible due to the presence of hydroxyl groups in the external and internal surfaces of MMT.

\section{Acknowledgment}

The author would like to thank Prof. Thomas AP Seery of the University of Connecticut for his insightful comments during the preparation of this article.

\section{References}

[1] Xie, W. - Gao, Z. - Pan, W-P. - Hunter, D. - Singh, A. - Vaia, R. (2001): Thermal degradation chemistry of alkyl quaternary ammonium montmorillonite. Chemistry of Materials. Vol. 13, No. 9, pp. 2979-90. https://doi.org/10.1021/cm010305s

[2] Alexandre, M. - Dubois, P. (2000): Polymer-layered silicate nanocomposites: preparation, properties and uses of a new class of materials. Materials Science and Engineering: R: Reports. Vol. 28. Nos. 1-2, pp. 1-63. https://doi.org/10.1016/S0927-796X(00)00012-7

[3] Tjong, S. C. - Meng, Y. Z. - Hay, A. S. (2001): Novel preparation and properties of polypropylene-vermiculite nanocomposites. Chemistry of Materials. Vol. 14, No. 1, pp. 44-51. https://doi.org/10.1021/cm010061b 
[4] Kotek, J. - Kelnar, I. - Studenovský, M. - Baldrian, J. (2005): Chlorosulfonated polypropylene: preparation and its application as a coupling agent in polypropylene-clay nanocomposites. Polymer. Vol. 46, No. 13, pp. 4876-81. https://doi.org/10.1016/j.polymer.2005.02.119

[5] Pramoda, K. P. - Liu, T. (2004). Effect of moisture on the dynamic mechanical relaxation of polyamide-6/clay nanocomposites. Journal of Polymer Science Part B: Polymer Physics. Vol. 42, No. 10, pp. 1823-30. https://doi.org/10.1002/polb.20061

[6] Penaloza, D. P. - Sandberg, D. J. - Giotto, M. V. - Seery, T. A. P. (2015): An exfoliated clay-poly(norbornene) nanocomposite prepared by metalmediated surface-initiated polymerization. Polymer Engineering and Science. Vol. 55, No. 10, pp. 2349-54. https://doi.org/10.1002/pen.24123

[7] Penaloza, D. P. (2016): Mechanical and thermal properties of claypoly(norbornene) nanocomposites from ruthenium alkylidene-mediated surface-initiated polymerization. Kimika. Vol. 27, No. 1, pp. 23-9. https://doi.org/10.26534/kimika.v27i1.22-28

[8] Penaloza, D. P. (2017): Review on the preparation, structure and property relation of clay-based polymer nanocomposites. Kimika. Vol. 28. No. 1, pp. 44-56. https://doi.org/10.26534/kimika.v28i1.44-56

[9] Bee, S-L. - Abdullah, M. A. A. - Bee, S-T. - Sin, L. T. - Rahmat, A. R. (2018): Polymer nanocomposites based on silylated-montmorillonite: A review. Progress in Polymer Science. Vol.85, pp. 57-82.

https://doi.org/10.1016/j.progpolymsci.2018.07.003

[10] Zhang, Z. H. - Li, T. S. - Yang, F. - Fu, C. G. (1998): Montmorillonite clay catalysis XI: Protection and deprotection of hydroxyl group by formation and cleavage of trimethylsilyl ethers catalysed by montmorillonite K- 10 . Synthetic Communications. Vol. 28, No. 16, pp. 3105-14.

https://doi.org/10.1080/00397919808004891

[11] Tyan, H. L. - Liu, Y. C. - Wei, K. H. (1999): Thermally and mechanically enhanced clay/polyimide nanocomposite via reactive organoclay. Chemistry of Materials. Vol. 11, No. 7, pp. 1942-7. https://doi.org/10.1021/cm990187x

[12] Francis, V. - Jain, P. K. (2018): Surface enhancement approach for FDM rapid prototypes by organically modified montmorillonite nanoparticles. IOP Conference Series: Materials Science and Engineering.Vol. 383, No. 1, pp. 012010. https://doi.org/10.1088/1757-899X/383/1/012010

[13] Zare, Y. - Rhee, K. Y. (2017): Multistep modeling of Young's modulus in polymer/clay nanocomposites assuming the intercalation/exfoliation of clay layers and the interphase between polymer matrix and nanoparticles. Composites Part A: Applied Science and Manufacturing. Vol. 102, pp. 13744. https://doi.org/10.1016/j.compositesa.2017.08.004

[14] Wang, W. - Zhao, Y. - Yi, H. - Chen, T. - Kang, S. - Li, H. - Song, S. (2018): Preparation and characterization of self-assembly hydrogels with exfoliated montmorillonite nanosheets and chitosan. Nanotechnology. Vol. 29, No. 2, pp. 025605. https://doi.org/10.1088/1361-6528/aa9ba4

[15] Dhatarwal, P. - Sengwa, R. J. - Choudhary, S. (2017): Effect of intercalated and exfoliated montmorillonite clay on the structural, dielectric and electrical properties of plasticized nanocomposite solid polymer electrolytes. Composites Communications. Vol. 5, pp.1-7. https://doi.org/10.1016/j.coco.2017.05.001

[16] Ji, J. - Ke, Y. - Pei, Y. - Zhang, G. (2017): Effects of highly exfoliated montmorillonite layers on the properties of clay reinforced terpolymer nanocomposite plugging microspheres. Journal of Applied Polymer Science. Vol. 134, No. 21, pp. 44894. https://doi.org/10.1002/app.44894

[17] Olphen, O. V. (1977): An introduction to clay colloid chemistry. Journal of Pharmaceutical Sciences. Vol 53, pp. 230-230. https://doi.org/10.1002/jps.2600530238

[18] Tjong, S. C. (2006): Structural and mechanical properties of polymer nanocomposites. Materials Science and Engineering: R: Reports. Vo. 53, Nos. 3-4, pp. 73-197. https://doi.org/10.1016/j.mser.2006.06.001

[19] Jeong, C. J. - Kang, E. B. - Park, S. J. - Choi, K. H. - Shin, G. - In, I. - Park, S. Y. (2015): Preparation of exfoliated montmorillonite nanocomposites with catechol/zwitterionic quaternized polymer for an antifouling coating. Polymer Engineering \& Science. Vol. 55, No. 9, pp. 2111-7. https://doi.org/10.1002/pen.24052

[20] Horst, M. F. - Quinzani, L. M. - Failla, M. D. (2014): Rheological and barrier properties of nanocomposites of HDPE and exfoliated montmorillonite. Journal of Thermoplastic Composite Materials. Vol. 27, No. 1, pp. 106-25. https://doi.org/10.1177/0892705712443248
[21] Follain, N. - Alexandre, B. - Chappey, C. - Colasse, L. - Médéric, P. Marais, S. (2016): Barrier properties of polyamide 12/montmorillonite nanocomposites: Effect of clay structure and mixing conditions. Composites Science and Technology. Vol. 136, pp. 18-28. https://doi.org/10.1016/j.compscitech.2016.09.023

[22] Endo, K. - Sugahara, Y. - Kuroda, K. (1994): Formation of intercalation compounds of a layered sodium octosilicate with $\mathrm{N}$-alkyltrimethylammonium ions and the application to organic derivatization. Bulletin of the Chemical Society of Japan. Vol. 67, No. 12, pp. 3352-5. https://doi.org/10.1246/bcsj.67.3352

[23] Ogawa, M. - Kuroda, K. (1997): Preparation of inorganic-organic nanocomposites through intercalation of organoammonium ions into layered silicates. Bulletin of the Chemical Society of Japan. Vol. 70, No. 11, pp. 2593-618. https://doi.org/10.1246/bcsj.70.2593

[24] Fudala, A. - Palinko, I. - Kiricsi, I. (1999): Preparation and characterization of hybrid organic-inorganic composite materials using the amphoteric property of amino acids: Amino acid intercalated layered double hydroxide and montmorillonite. Inorganic Chemistry. Vol. 38, No. 21, pp. 4653-8. https://doi.org/10.1021/ic981176t

[25] Matsumoto, A. - Odani, T. - Sada, K. - Miyata, M. - Tashiro, K. (2000): Intercalation of alkylamines into an organic polymer crystal. Nature. Vol. 405, No. 6784, pp. 328-30. https://doi.org/10.1038/35012550

[26] Pálková, H. - Zimowska, M. - Jankovič, L. - Sulikowski, B. - Serwicka, E. M. - Madejová, J. (2017): Thermal stability of tetrabutyl-phosphonium and -ammonium exchanged montmorillonite: Influence of acid treatment. Applied Clay Science. Vol. 138, pp. 63-73. https://doi.org/10.1016/j.clay.2016.12.043

[27] Osman, M. A. - Ploetze, M. - Skrabal, P. (2004): Structure and properties of alkylammonium monolayers self-assembled on montmorillonite platelets. The Journal of Physical Chemistry B. Vol. 108, No. 8, pp. 2580-8. https://doi.org/10.1021/jp0366769

[28] Fornes, T. D. - Yoon, P. J. - Hunter, D. L. - Keskkula, H. - Paul, D. R. (2002) Effect of organoclay structure on nylon 6 nanocomposite morphology and properties. Polymer. Vol. 43, No. 22, pp. 5915-33. https://doi.org/10.1016/S0032-3861(02)00400-7

[29] Huskic, M. - Zagar, E. - Zigon, M. - Brnardic, I. - Macan, J. - Ivankovic, M. (2009): Modification of montmorillonite by cationic polyesters. Applied Clay Science. Vol. 43, No. 3-4, pp. 420-4. https://doi.org/10.1016/j.clay.2009.01.008

[30] Xie, W. - Gao, Z. - Liu, K. - Pan, W-P. - Vaia, R. - Hunter, D. - Singh, A. (2001): Thermal characterization of organically modified montmorillonite. Thermochimica Acta. Vol. 367-368, pp. 339-50. https://doi.org/10.1016/S0040-6031(00)00690-0

[31] Kooli, F. (2009): Thermal stability investigation of organo-acid-activated clays by TG-MS and in situ XRD techniques. Thermochimica Acta. Vol. 486, Nos. 1-2, pp. 71-6. https://doi.org/10.1016/j.tca.2008.12.025

[32] Lagaly, G. (1986): Interaction of alkylamines with different type of layered compounds. Solid State Ionics. Vol. 22, pp. 43-51. http://dx.doi.org/10.1016/0167-2738(86)90057-3

[33] Fu, Y-T. - Heinz, H. (2010): Structure and cleavage energy of surfactant-modified clay minerals: Influence of CEC, head group and chain length. Philosophical Magazine. Vol. 90, No. 17, pp. 2415-24. https://doi.org/10.1080/14786430903559490

[34] Kloprogge, J. T. (1998): Synthesis of smectites and porous pillared clay catalysts: a review. Journal of Porous Materials. Vol. 5, No. 1, pp. 5-41. https://doi.org/10.1023/A:1009625913781

[35] Osman, M. A. - Ernst, M. - Meier, B. H. - Suter, U. W. (2001): Structure and molecular dynamics of alkane monolayers self-assembled on mica platelets. The Journal of Physical Chemistry B. Vol. 106, No. 3, pp. 653-62. https://doi.org/10.1021/jp0132376

[36] Vaia, R. A. - Teukolsky, R. K. - Giannelis, E. P. (1994): Interlayer structure and molecular environment of alkylammonium layered silicates. Chemistry of Materials. Vol. 6, No. 7, pp. 1017-22. https://doi.org/10.1021/cm00043a025

[37] Hackett, E. - Manias, E. (1998): Molecular dynamics simulations of organically modified layer silicates. Journal of Chemical Physics. 1998;108(17):7410. https://doi.org/10.1063/1.476161 
[38] Blumstein, A. (1965): Polymerization of adsorbed monolayers. II. Thermal degradation of the inserted polymer. Journal of Polymer Science Part A: General Papers. Vol. 3, No. 7, pp. 2665-72. https://doi.org/10.1002/pol.1965.100030721

[39] Krishnamoorti, R. - Vaia, R. A. - Giannelis, E. P. (1996): Structure and dynamics of polymer-layered silicate nanocomposites. Chemistry of Materials. Vol. 8, No. 8, pp. 1728-34. https://doi.org/10.1021/cm960127g

[40] Utracki, L. A. - Sepehr, M. - Boccaleri, E. (2007): Synthetic, layered nanoparticles for polymeric nanocomposites (PNCs). Polymers for Advanced Technologies. Vol. 18, No. 1, pp. 1-37.

https://doi.org/10.1002/pat.852

[41] Ray, S. S. - Okamoto, K. - Okamoto, M. (2003): Structure-property relationship in biodegradable poly(butylene succinate)/layered silicate nanocomposites. Macromolecules. Vol. 36, No. 7, pp. 2355-67. https://doi.org/10.1021/ma021728y

[42] Lee, S. Y. - Kim, S. J. (2003): Dehydration behavior of hexadecyltrimethylammonium-exchanged smectite. Clay Minerals. Vol. 38, No. 2, pp. 225-32. https://doi.org/10.1180/0009855033820091

[43] Fan, X. - Zhou, Q. - Xia, C. - Cristofoli, W. - Mays, J. - Advincula, R. (2002): Living anionic surface-initiated polymerization (LASIP) of styrene from clay nanoparticles using surface bound 1,1-diphenylethylene (DPE) initiators. Langmuir. Vol. 18, No. 11, pp. 4511-8. https://doi.org/10.1021/la025556+

[44] Zhou, Q. - Fan, X. - Xia, C. - Mays, J. - Advincula, R. (2001): Living anionic surface initiated polymerization (SIP) of styrene from clay surfaces. Chemistry of Materials. Vol. 13, No. 8, pp. 2465-7. https://doi.org/10.1021/cm0101780

[45] Herrera, N. N. - Letoffe, J. M. - Putaux, J. L. - David, L. - Bourgeat-Lami, E. (2004): Aqueous dispersions of silane-functionalized laponite clay platelets. A first step toward the elaboration of water-based polymer/clay nanocomposites. Langmuir. Vol. 20, No. 5, pp. 1564-71. https://doi.org/10.1021/la0349267

[46] Romanzini, D. - Frache, A. - Zattera, A. J. - Amico, S. C. (2015): Effect of clay silylation on curing and mechanical and thermal properties of unsaturated polyester/montmorillonite nanocomposites. Journal of Physics and Chemistry of Solids. Vol. 87, pp. 9-15.

https://doi.org/10.1016/j.jpcs.2015.07.019

[47] He, H. P. - Duchet, J. - Galy, J. - Gerard, J. F. (2005): Grafting of swelling clay materials with 3-aminopropyltriethoxysilane. Journal of Colloid and Interface Science. Vol. 288, No.1, pp. 171-6. https://doi.org/10.1016/j.jcis.2005.02.092

[48] Zhang, J. G. - Gupta, R. K. - Wilkie, C. A. (2006): Controlled silylation of montmorillonite and its polyethylene nanocomposites. Polymer. Vol. 47, No. 13, pp. 4537-43. https://doi.org/10.1016/j.polymer.2006.04.057

[49] Okutomo, S. - Kuroda, K. - Ogawa, M. (1999): Preparation and characterization of silylated-magadiites. Applied Clay Science. Vol. 15, No. 1-2, pp. 253-64. https://doi.org/10.1016/S0169-1317(99)00010-1

[50] Ogawa, M. - Okutomo, S. - Kuroda, K. (1998): Control of interlayer microstructures of a layered silicate by surface modification with organochlorosilanes. Journal of the American Chemical Society. Vol. 120, No. 29, pp. 7361-2. https://doi.org/10.1021/ja981055s

[51] Deuel, H. - Huber, G. - Iberg, R. (1950): Organische derivate von tonmineralien. Helvetica Chimica Acta. Vol. 33, No. 5, pp. 1229-32. https://doi.org/10.1002/hlca.19500330514

[52] Letoffe, J-M. - Putaux, J-L. - David, L. - Bourgeat-Lami, E. (2004) Aqueous dispersions of silane-functionalized laponite clay platelets. A first step toward the elaboration of water-based polymer/clay nanocomposites. Langmuir. Vol. 20, No. 5, pp. 1564-71. https://doi.org/10.1021/la0349267
[53] Song, K. - Sandi, G. (2001): Characterization of montmorillonite surfaces after modification by organosilane. Clays and Clay Minerals. Vol. 49, No. 2, pp. 119-25.

[54] Herrera, N. N. - Letoffe, J-M. - Reymond, J-P. - Bourgeat-Lami, E. (2005): Silylation of laponite clay particles with monofunctional and trifunctional vinyl alkoxysilanes. Journal of Materials Chemistry. Vol. 15, No. 8, pp. 86371. https://doi.org/10.1039/B415618H

[55] Lee, D. C. - Jang, L. W. (1996): Preparation and characterization of PMMA-Clay hybrid composite by emulsion polymerization. Journal of Applied Polymer Science. Vol. 61, No. 7, pp. 1117-22.

https://doi.org/10.1002/(SICI)1097-4628(19960815)61:7<1117::AID-APP7>3.0.CO;2-P

[56] Park, M. - Shim, I-K. - Jung, E-Y. - Choy, J-H. (2004): Modification of external surface of laponite by silane grafting. Journal of Physics and Chemistry of Solids. Vol. 65, Nos. 2-3, pp. 499-501. https://doi.org/10.1016/j.jpcs.2003.10.031

[57] Wheeler, P. A. - Wang, J. - Baker, J. - Mathias, L. J. (2005): Synthesis and characterization of covalently functionalized laponite clay. Chemistry of Materials. Vol. 17, No. 11, pp. 3012-8. https://doi.org/10.1021/cm050306a

[58] Ruiz-Hitzky, E. - Fripiat, J. J. (1976): Organomineral derivatives obtained by reacting organochlorosilanes with the surface of silicates in organic solvents. Clays and Clay Minerals. Vol. 24, No. 1, pp. 25-30. https://doi.org/10.1346/CCMN.1976.0240102

[59] Ruiz-Hitzky, E. R. - Rojo, J. M. (1980): Intracrystalline grafting on layer silicic acids. Nature. Vol. 287, pp. 28-30. https://doi.org/10.1038/287028a0

[60] Ruiz-Hitzky, E. R. - Rojo, J. M. - Lagaly G. (1985): Mechanism of the grafting of organosilanes on mineral surfaces. Colloid \& Polymer Science. Vol. 263, No. 12, pp. 1025-30. https://doi.org/10.1007/BF01410996

[61] Thiesen, P. H. - Beneke, K. - Lagaly, G. (2002): Silylation of a crystalline silicic acid: an MAS NMR and porosity study. Journal of Materials Chemistry. Vol. 12, No. 10, pp. 3010-5. https://doi.org/10.1039/B204314A

[62] Eugster, H. P. (1967): Hydrous sodium silicates from Lake Magadi, Kenya: precursors of bedded chert. Science. Vol. 157, No. 3793, pp. 1177-80. https://doi.org/10.1126/science.157.3793.1177

[63] Chen, G-X. - Choi, J. B. - Yoon, J. S. (2005): The role of functional group on the exfoliation of clay in poly(L-lactide). Macromolecular Rapid Communications. Vol. 26, No. 3, pp. 183-7. https://doi.org/10.1002/marc.200400452

[64] Chen, G-X - Kim, H-S - Shim, J-H - Yoon, J-S. (2005): Role of epoxy groups on clay surface in the improvement of morphology of poly(1lactide)/clay composites. Macromolecules. Vol. 38, No. 9, pp. 3738-44. https://doi.org/10.1021/ma0488515

[65] Wheeler, P. A. - Wang, J. - Mathias, L. J. (2006): Poly(methyl methacrylate)/laponite nanocomposites: exploring covalent and ionic clay modifications. Chemistry of Materials. Vol. 18, No. 17, pp. 3937-45. https://doi.org/10.1021/cm0526361

[66] Yanagisawa, T. - Kuroda, K. - Kato, C. (1988): Organic derivatives of layered polysilicates. II. Reaction of magadiite and kenyaite with diphenylmethylchlorosilane. Bulletin of the Chemical Society Japan. Vol. 61, No. 10, pp. 3743-3745. https://doi.org/10.1246/bcsj.61.3743

$\underline{\text { Ref.: }}$

Penaloza, David P. Jr.: Modified clay for the synthesis of clay-based nanocomposites

Építőanyag - Journal of Silicate Based and Composite Materials, Vol. 71, No. 1 (2019), 5-11. p. https://doi.org/10.14382/epitoanyag-jsbcm.2019.2

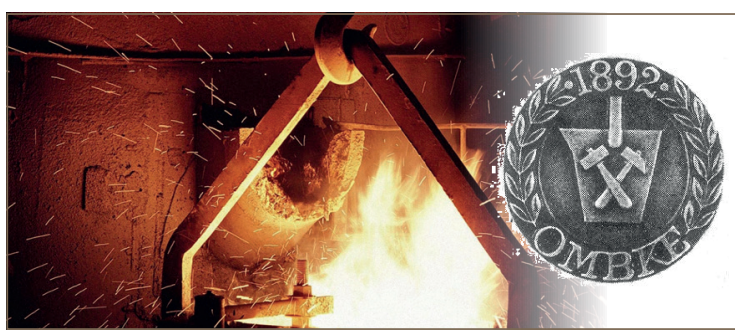

